\title{
How Principal Value and Retailer in the Paint Industry Context in Southeast Asian? A Literature Review
}

\author{
Prita Prasetya ${ }^{1 *}$, Mukhamad Najib $^{2}$, Agus W Soehadi ${ }^{3}$ and Setiadi Djohar \\ ${ }^{1}$ School of Business, Bogor Agricultural University, Bogor, Indonesia \\ ${ }^{2}$ Department of Management, Bogor Agricultural University, Bogor, Indonesia \\ ${ }^{3}$ Prasetiya Mulya Business School of Management, Jakarta, Indonesia \\ ${ }^{4}$ PPM School of Management, Jakarta, Indonesia \\ *Corresponding author: pritaprasetya@gmail.com
}

\begin{abstract}
Research in marketing channel proves that managing relationship between partners, both individuals, and organizations, that manage distribution functions are very important. Successful principals require proper management of distribution channel to provide the best business performance. The management of marketing channel has been widely discussed as an important element in the supply chain and retail trading. Research on distribution channels generally takes economic concepts that explain distribution channels as a flow of goods and services. Interaction between principal and agent is the benefits optimization or minimization of costs, and neglect of non-economic factors. The development of research on channel management leads to non-economic factors which are describe the relationship between channel partners as a new era in principal and retailers relationships. The concept of relationship value is a social exchange theory aims to build long-term and sustainable relationships between partners.

\section{Highlights}

( New concept of marketing relationship model in channel management, drivers that affect relationship value to improving retailer performance.

(0) The four factors include personal value, financial value, knowledge value, and strategic value.

( High performance of relationship value will lead to more efficient and effective retailer transactions, then it is expected that the relationship will continue in the future so as to improve profitability.
\end{abstract}

Keywords: Value, Principal, Distribution channel, Retailer Performance

The growth of the paint industry in Southeast Asian countries has increased steadily. The combination of CGR value from Malaysia, Indonesia, Myanmar, Kamboja, and Laos was 7.7\%, growing from USD 1,224.0 million in 2016 to USD 1,772.4 million in 2021 (Frost and Sullivan, 2017). It was driven by economic growth, increased housing development and commercial areas including the opening of MEA trading channel. Segmentation in the paint industry in most countries in Southeast Asia is divided based on the function and type of paint: decorative and non-decorative paints (Fig. 1).

Decorative paint or known as architectural coating, this segment includes all coatings that are applied to new and existing buildings, both residential, commercial or industrial for decorative purposes.

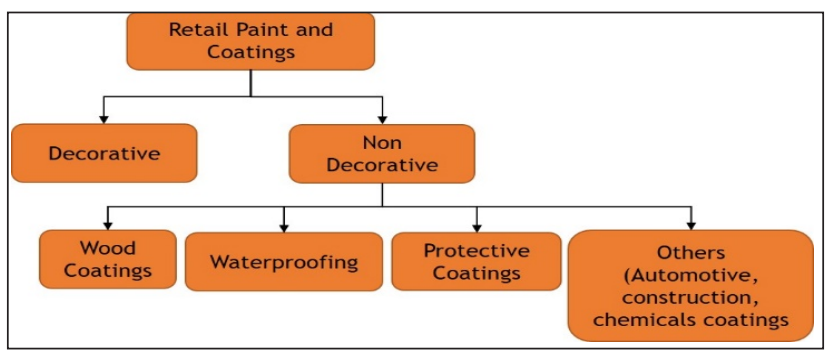

Fig. 1: Segmentation Retail Paint and Coatings

Non-decorative paint is divided into three segments that are wood coating, waterproofing, metal and concrete and others (cars, construction, and 
CD Prasetya et al.

chemicals). Paint distribution channels mainly through retail sales and projects. The project channel is done by a principal method which is selling directly to the construction company or project developer as the final user. Sales through retail channels are carried out by distributing paint to traditional and modern stores both directly and through distributors. Distributors act as intermediaries who will distribute paint to retail for sale to consumers (Fig. 2).

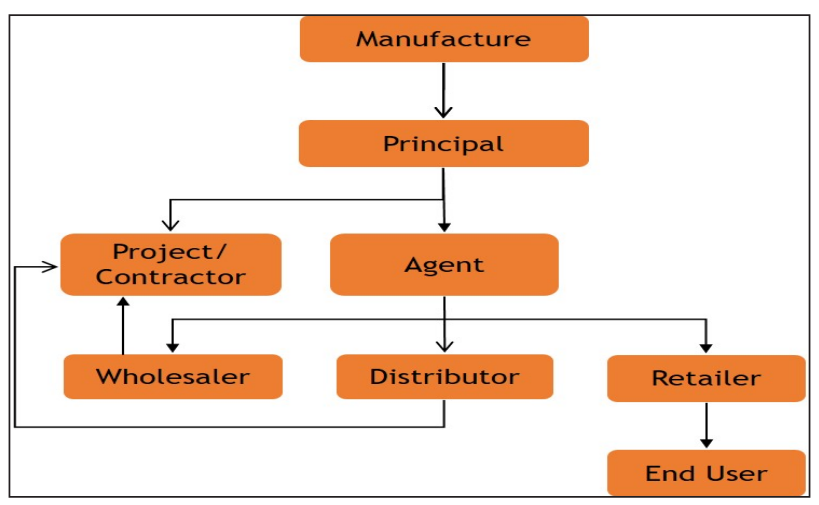

Fig. 2: Value Chain Paint and Coatings

Competition in the paint industry in the retail segment is very tight. It can be seen from many paint brands. Besides product factors, distribution channels also play an important role in this business, both traditional and modern outlets (MARS, 2014). The main challenge for paint manufacturers in building partnerships with retailers is how to build a mutually beneficial relationship in the long-term. Research and practice of marketing channel management have proven the importance of managing a relationship between individuals or organizations that carry out distribution functions (Weitz and Jap, 1995a). The proper marketing channel management will produce a business performance in accordance with the target. The relationship between principals and retailers in paint distribution channel shows that the interdependence of both provides a different perspective. The manufacturer's point of view sees that to increase market share, more retailers are needed in one area. While retailers consider that the increasing number of competitors that selling the same product, it will reduce the number of sales. Therefore, we need a better understanding of work relations between distribution channels, in this case, principals and retailers. The concept of paint marketing in retail channels is not just discussed transactional marketing that focuses on product, distribution, advertising, meeting consumer needs, and sales issues. Because the quality of paint products are equivalent to the same distribution system. Therefore, to achieve optimal business performance, the proper strategy is needed. In business interactions, it is very rare for pure transactions to occur without a relationship. The concept that is widely applied in an industrial relationship is relational marketing, to the building, maintaining, and improving the relationship with customers. In this study, such as principals and retailers. The purpose of relationship marketing is to improve the mutually beneficial relationship and require an obvious focus in order to produce value to customers (Palmatier, 2008). This is a reason for principals to invest resources in the relationship. They can provide benefits and higher values than expected. Building a long-term relationship can help companies and customers to create higher value than just a mutually beneficial and economically oriented relationship. Companies must be able to create relationship value with customers to create and maintain relationships than grow into stronger and more sustainable bonds.

\section{Literature Review}

\section{Channel Management}

Distribution channels are a group of interdependent organizations that helping to make available products or services to be used or consumed by consumers or business users. Marketing channels have important functions, including: get information about consumers, competitors, and marketing environment; develop communication to stimulate purchases; find agreement on prices and other supporting components; provide estimates of orders to manufacturers; collect and distribute products through marketing channels; provide credit and other purchasing options for consumers; and supervise the actual sales of products or services to consumers and businesses (Levens, 2014).

Marketing channels are one of the important elements in the value chain and distribution channel is one of the main functions in retail trading. Important functions of marketing channels include: gathering information about consumers, competitors, and marketing environment and 
developing communication to stimulate purchases (Stern and Palmatier, 2014). Management in marketing channels is the main issue faced by the principal. In the dyadic relationship between principal and retailers, the complexity of managing marketing channel management is not only focused on the selection of distribution channel strategies but also maintains a relationship between them using the relational approach. A marketing channel is a place where the process of creating customer value occurs on the supply chain, so it requires manufacturers to understand the important factors that can encourage the creation of relationship value (Kozlenkova et al. 2015).

\section{Marketing Channel Evolution}

The importance of managing the relationship in marketing channel has been studied. The initial research mostly came from concepts in the economic field, such as looking distribution channel as a flow of goods and services. Research in the early 20th century identified interactions among companies as optimization or minimization of costs. Vertical marketing systems saw as company expansion and ignore non-economic factors. Research on marketing channel is more prescriptive, designing management decision patterns that are responsible simultaneously for cost functions, revenue opportunities, and information. Furthermore, by using institutional functional, organizational and system approaches to understand marketing channel, the research develops and recognizes the results of empirical studies about non-economic factors in the marketing channel. Behavior view has focused on the other function of distribution channels such as organizational patterns in the distribution system and behavioral factors that influence the channel.

Many new research opportunities have emerged to illustrate the relationship between channeling and integrating theories relating to the main roles of channels: communication, conflict, power of channel strategy, distribution and channel structure, conflict management, and opportunism. Moreover, research moves beyond previous theories which are dominated by economic approaches and begin to use social theories: sociology, psychology, and political science (Krafft et al. 2015). The dyadic study uses economic theory and behavioral approach aims to understand the characteristic of exchange, and then describes the interactions between exchange partners by designing strategies for performance improvement. The development of theory in the dyadic channel (Fig. 3).

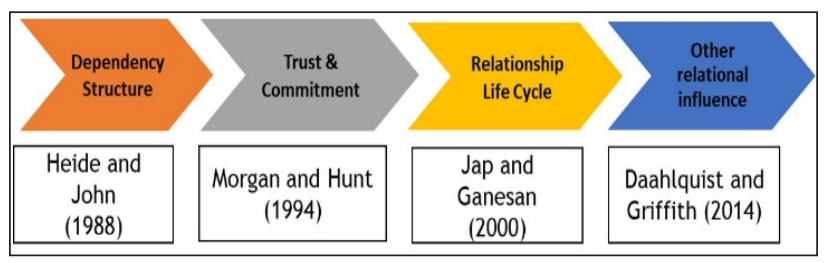

Fig. 3: Dyadic channel research theory

Discusses the structure of dependence between principal and agent (Heide and John, 1988), trust and commitment (Morgan and Hunt, 1994), the relationship of the life cycle (Jap, 2012). Recent research shows that interfirm relationship is influenced by other relational influence. On the whole, the research channel has shifted towards a more positive focus on relational constructs such as trust and commitment. Behavior-based theory and construction are more important than the economicbased theory and construction. This shift reflects the emergence of a general view among demographics and practitioners who distribute systems that are interconnected with a network of socially bound social entities. The long term cooperation is very important for success for them (Watson et al. 2015).

The success of a company in running a business with their marketing channel is by identifying and managing drivers of performance between organizations. This driver aims to improve financial performance and competitive supremacy. Literature has discussed a lot of driver channel performance (figure 4) using a political economy theory and approach, dependence, inter-organizational governance, and marketing relationship. Political economy theory shows that economic forces and socio-political power interact in producing performance (Stern, L.W. and Reve, 1980). Centralization can increase the effectiveness and efficiency of marketing channels. Formalization can improve coordination which leads to superior economic performance. With cooperative behavior, the entire channel system can achieve higher financial performance.

Dependence theory shows that there is a positive relationship with channel performance. Some 
C) Prasetya et al.

empirical studies provide many results about the drivers of channel performance: power, communication, leadership, cooperation, and conflict. Channel conflicts arise when channel member behavior conflicts with their channel partners (Frazier and Rody, 1991). Inter-organizational driver deals with the process of building, compiling, and monitoring relationship exchanges (Heide, 1994). Channel performance improved when the governance fit with the exchange of dimensions. Channel performance was driven with the specific investment, relational norms, and monitoring relationship. Relationship marketing centers on the role of relationship (Morgan and Hunt, 1994). Some empirical studies show a positive relationship among channel performance with satisfaction, commitment, trust, and relationship quality. However, some studies have failed to influence channel performance such as relationship longevity and continuity (Kang et al. 2018).

\section{Relationship Marketing}

At first, the marketing concept focuses on exchange or transaction process, then develops into a valuebased relationship and marketing networks. It is known as relationship marketing. The current trend of marketing is a shift of traditional approach towards a relationship approach focuses on customer need and satisfaction. The transactional approach emphasizes individual relationship rather than togetherness. This marketing approach only pays attention to how to get customers, without paying attention to how to maintain customers. Marketing relationship is part of the marketing concept that involves all activities in the exchange process (Sheth, 2017). The concept of relational marketing is based on:

1. The concept of exchange involving many parties (stakeholders).

2. A relational exchange that relates to the behavior of actors (individuals or organizations) on interacting, both final consumers and organizational actors.

3. Mutually beneficial relationship.

4. Orientation to create a harmonious relationship with all stakeholders.

5. Long-term relational orientation (lifetime value relationship).
Marketing relationship focuses on the pattern of a harmonious relationship between stakeholders both intra-relationship and inter-relationship. Intrarelationship is related to the relational relationship with stakeholders in an organization, while interrelationship is a relationship with stakeholder outside the organization. Inter-relationship for the company is a relationship built by the company with external parties both individual customers and organizations. (Sheth, 2017) view marketing relationship as an orientation that aims to develop a close relationship with customers, suppliers, and certain competitors for value creation through collaborative efforts. It was also added that the purpose of marketing relationship is to grow, develop, and maintain the success of relationship exchanges. If it is related to a distribution channel, it means developing a long-term relationship between channel members that involves a generic set of relationship development processes. It is include initiating, maintaining and terminating the relationship. Research in channel management has proven the importance of managing relationships between people and companies that carry out the distribution function (Weitz and Jap, 1995b).

\section{Relationship Value}

The concept of relationship value is social exchange theory which is brought into a business for business transactions by researchers (Eiriz and Wilson, 2006; Ulaga and Eggert, 2001; Wilson and Jantrania, 1994). Based on the assumptions of social exchange theory, economic or social benefits are the result of social interactions between individuals or organizations. Social exchange theory focuses on a long-term relationship and sustainable exchanges between partners both individuals and organizations (Tanskanen and Aminoff, 2015). Furthermore, the social exchange theory also introduces a time factor in relational exchanges. Its results are future and cost benefits depending on the time, experience and predictions of future results from the exchange. Only organizations that provide value to customers can maintain a long-term relationship (Richards and Jones, 2008). Anderson et al. 1994 emphasized that the value of the relationship is specific. It means that it is connected to social and personal values. Two organization involved in commercial exchanges create a kind of "hybrid organization" that brings 
the long-term relationship with the aim of providing values more than the number of individual values made by each organization. It means that the efficiency and effectiveness of the resources used by two organizations exist in relational interactions is greater than the efficiency and effectiveness that the organization can achieve individually.

Factors that influence the value of relationship consist of measurable and non-measurable factors as well as tangible and non-tangible benefits (Matear and Baxter, 2003). In the industrial context especially the dyadic relationship between buyerseller, the relationship value is seen from the perspective of both parties that is suppliers and customers (Corsaro et al. 2010). Business partners in a relationship can offer a variety of value (Pimpa, 2008). Therefore, the relationship between partners is based on the presence or absence of values. Choosing the right supplier will help buyers to improve their perceptions of the benefits to be obtained from suppliers if they establish cooperative relationships (Kannan and Tan, 2006). Ulaga and Eggert (2006) develop a model for creating differentiation by creating value in manufacturing and supplier relationships where the dimensions of relationship value are the relationship between benefits and costs.

\section{Relationship Value of Drivers}

Research has been done by marketing experts continuously examine many constructions that build the value of relationships, consequences and factors that moderate or mediate relationships. Marketing theory has argued that value is what must be made, delivered and valued by the company. Values are generally seen as an exchange of benefits and sacrifices associated with exchange relation and as a source of competitive supremacy. Companies do business with each other and develop a close working relationship from a value-based perspective. Value creation must be the goal and the final result of the business relationship, and function as a standard for the effectiveness of relationship marketing activities and the success of relationship assessed. The more companies try to build an international market through intercompany relation; there is a need to develop a better understanding of the value obtained from this relationship.
Companies usually only focus on consumer perceptions about the exchange of benefits and sacrifices which is related to goods or services. However, several studies have examined the fundamental role of the relationship value in the business market. Companies do business with each other not only about the value of products exchanged but also for the other factors such as partner reputation, experience, innovation, location and knowledge of product and market (Lindgreen et al. 2012). Thus, the value in business relationship exceeds price versus trade-off quality which usually occurs in consumers to cover the relational dimension. Relationship value refers to the overall assessment of a relationship based on cost and benefit perceptions (Blocker et al. 2012; Ulaga and Eggert, 2006). Companies can develop relationships that produce value. Therefore it will produce sustainable competitive supremacy.

The value created by a relationship can be generated from sharing knowledge, technology and other resources. Wilson and Jantrania (1994) stated that value creation occurs in a social, economic and political context in which the company is located. The value of the relationship is constructed from three dimensions: economic, behavioral and strategic. Ford and Mcdowell (1999) emphasize the value of relationship beyond financial problems, values are obtained from the sharing of knowledge, reputation, and network access. Day G.S. (2000) emphasizes that strategic values and personal relationships are the foundation for building competitive supremacy. Most of the marketing literature addresses the value of relationship focuses on financial value. The lack of empirical research that produces a more comprehensive perspective on building relationship values (Biggemann and Buttle, 2012). This study integrates the concept of value based on a relational approach. The value of relationship in business is more than the concept of costs and benefits. There are four factors influencing the value of relationship that is personal value, financial value, knowledge value, and strategic value.

\section{Personal Value}

The value given to a relationship can be related to one's feelings about his role in society. The expected results of actions in a relationship are influenced by the individual. Most individuals provide value 
on a limited relationship based on their personal interpretations. Ford and Mcdowell (1999) define value as something related to one's personal belief. Barnes (2003) understands the value of the feelings and emotions of customers or called as emotional value. Individual factors are very influential in maintaining a relationship. The value given to a relationship relates to individual feelings in the social environment. According to Biggemann and Buttle (2012), personal value is a situation where one party approves or accepts the actions of another in an unusual situation. Personal value indicators can be seen when manufacturers prefer to help customers or tolerate special situation so that they can prevent the termination of the relationship. In addition, the personal value can be seen from customer retention and the existence of references from customers to other parties, so that it can lead to the creation of financial value (Werner J. et al. 2003).

Personal value is an important factor in the buyerseller relationship. It is similar to know detailed information about customers and maintain a good relationship with customers. Customers will feel satisfied with marketers who have the ability to interact with them and able to read the feelings, attitudes, and beliefs of customers in social interactions (Ulaga and Eggert, 2003). The same result also expressed by Pels et al. (2004) who argue that developing personal value is the antecedent of the value of customer satisfactionbased relationships. Personal interactions have a positive impact and many benefits in long-term relationships between companies and customers such as social benefits like friendship and personal recognition. Psychological benefits such as reducing the anxiety of credit. Economic benefits such as discounts and saving time (Lam, 2004). Indicators of personal value can be seen from the availability of personnel from principals, ease of contacting personnel, interaction, and decision making process, and the nature of courtesy and friendliness, the existence of interest and relevance in establishing relationships, ability to build cooperative networks, problem solving skills and ability to reduce worries (Lefaix-Durand et al. 2009). Continuous personal interaction between companies and customers will be a social relationship asset obtained by the customer.

\section{Financial Value}

The value of the relationship is seen as a comparison of costs and benefits, however, it is not easy to assess relationship value from financial factors based on the relationship between costs and benefits. Biggemann and Buttle (2012) stated that relational based financial value identifies indicators of financial value, that a very close relationship to the customers is an intangible asset and financially valuable when the business will be prepared for sale or called as "goodwill". The contract sale was predominantly prevailed as 'mode of sale' in the area. The 'cash sale' as-well-as 'credit sale' was prevailing in the area. The marginal and small category growers sold banana to the pre-harvest contractors (Kumari et al. 2018). The belief about the quality of the relationship will help companies meet their sales targets. In the broader view, close relationships with retailers will increase business opportunities and efficiency as a result of better planning. Even with such closeness, it will create confidence from principals that the customer will obtain satisfaction in business relationship related to economic results (Geyskens et al. 2006), by increasing profitability (Payne et al. 2008).

Financial value is associated with economic satisfaction, indicated by increased efficiency, getting more business share, more market share, and the desire of customers to pay more. Economically, success in business relationships is an indicator of achieving goals in relationship such as effectiveness, productivity, and performance produced.

\section{Knowledge Value}

Knowledge-based value defines that relationship can also provide in the form of sharing and creating knowledge, encourage the creation of new ideas, sharing more detailed information or market intelligence regarding market conditions as a form of meeting the demands of a growing market. Closer relationship will provide opportunities for communication that allow parties to share information. Partners will exchange information about market intelligence. The value of the relationship is the creation of dynamic ideas that emerged from both parties "idea generation" (Biggemann and Buttle, 2012). The value of knowledge is an important factor in producing competitive supremacy (Dyer and Singh, 1998). 
Literature divides knowledge into two types: information and knowledge. Information is defined as knowledge that is easily codified and can be transmitted without losing integrity and bound to syntactic rules needed to interpret. Information includes facts, axiomatic propositions, and symbols. Knowledge involves quiet, rigid, complicated and difficult to codify (tacit), difficult to imitate and move. However, these characteristics also show that knowledge (know-how) allows producing sustainable profits which can outperform the competitors. Thus, parties can find new ways to manage and develop better business processes and make innovations together. Ballantyne (2004) stated that the emergence of special knowledge in relationships is socially built and created together among partners. The value of knowledge will enable the emergence of innovative solutions and enhance the relationship of mutual understanding and create credibility. Knowledge value is also seen as value co-creation (Payne et al. 2008; Skarmeas et al. 2015).

\section{Strategic Value}

Strategic value is produced from increased stability and reduced uncertainty provided by partners in a relationship, allowing them to extend planning time. Strategic values provide reduce risk, enable better utilization of assets and opportunities to build new business foundations (Biggemann and Buttle, 2012). The strategic value will emerge as a result of the relationship to increase the company's competitiveness. The idea of obtaining benefits from the expansion of business networks in a relationship is called anticipated constructive effect on network identity (Anderson and Narus, 1990; Lewin et al. 2008).

Möller and Törrönen (2003) stated that the network function among suppliers is to utilize networks or suppliers as resources to gain wider access. The strategic value of relationships can be indicated through long-term planning and expansion of relationship networks. According to Day (2000), strategic value is an important factor in the value of relationships. The ability to create and maintain a relationship provides the foundation for building competitive supremacy. High strategic values are generally seen as a source of competitive supremacy (Skarmeas et al. 2015; Ambler, 2001).

\section{ACKNOWLEDGEMENTS}

The author would like to thank all the author of journal review, have give some information for providing inspire fellowship to undertake the review

\section{CONCLUSION}

Distribution channels are very important in the marketing of paint products in the retail market, especially marketing through retailers which are the main distribution channels. The main challenge for principals in building cooperation with retailers is how to build mutually beneficial relationships amid increasingly fierce competition. Therefore, it is necessary to manage a better relationship in the long-term. Most of the studies on relationship value are carried out using transaction cost approach focuses on tradeoff between benefits and sacrifices. Meanwhile, in creating the value of the relationship between principals and retailers, especially paint products, this approach is no longer relevant. It needs a more comprehensive approach. Distribution channels are seen as a flow of goods and services. Most principal-agent interactions are only considering economic factors such as optimization and minimization. This study tries to propose a new concept of marketing relationship model in channel management, drivers that affect relationship value to improving retailer performance. The four factors include personal value, financial value, knowledge value, and strategic value. High performance of relationship value will lead to more efficient and effective retailer transactions, then it is expected that the relationship will continue in the future so as to improve profitability.

\section{REFERENCES}

Ambler, T. 2001. Value-based marketing: Marketing strategies for corporate growth and shareholder value. Journal of Brand Management, 8(6): 463-466.

Anderson, J.C. and Narus, J.A. 1990. A Model of Distributor Firm and Manufacturer Firm Working Partnerships. Journal of Marketing, 54(1): 42.

Ballantyne, D. 2004. Dialogue and its role in the development of relationship specific knowledge. Journal of Business and Industrial Marketing, 19(2): 114-123.

Barnes, J.G. 2003. Establishing meaningful customer relationships: Why some companies and brands mean more to their customers. Managing Service Quality: An International Journal, 13(3): 178-186. 
C) Prasetya et al.

Biggemann, S. and Buttle, F. 2012. Intrinsic value of businessto-business relationships: An empirical taxonomy. Journal of Business Research, 65(8): 1132-1138.

Blocker, C.P., Cannon, J.P., Panagopoulos, N.G. and Sager, J.K. 2012. The Role of the Sales Force in Value Creation and Appropriation: New Directions for Research. Journal of Personal Selling and Sales Management, 32(1): 15-28.

Corsaro, D., Italiana, S., Snehota, I. and Italiana, S. 2010. Searching for Relationship Value in Business Markets. Industrial Marketing Management, 39(6): 1-15.

Day G.S. 2000. Managing Market Relationships. Journal of the Academy of Marketing Science, 28(1): 24-31.

Dyer, J. H. and Singh, H. 1998. The relational view: Cooperative strategy and sources of interorganizational competitive advantage. Academy of Management Review, 23(4): 660-679.

Eiriz, V. and Wilson, D. 2006. Research in relationship marketing: Antecedents, traditions and integration. European Journal of Marketing, 40(3-4): 275-291.

Ford, D. and Mcdowell, R. 1999. Developing business relationships. pdf, 442, 429-442.

Frazier, G.L. and Rody, R.C. 1991. The Use of Influence Strategies in Interfirm Relationships in Industrial Product Channels. Journal of Marketing, 55(1): 52.

Frost and Sullivan. 2017. Independent Market Research on the Paint and Coating Industry in Selected Southeast Asian Countries.

Geyskens, I. and Steenkamp, J.K.N. 2006. Make, Buy, or Ally: A Transaction Cost Theory Meta Analysis. The Academy of Management Journal, 49(3): 519-543.

Heide, J.B. 1994. Interorganizational Governance in Marketing Channels. Journal of Marketing, 58(1).

Heide, J.B. and John, G. 1988. The Role of Dependence Balancing in Safeguarding Transaction-Specific Assets in Conventional Channels. Journal of Marketing, 52(1): 20.

Jap, S.D. 2012. Efforts : Processes in Collaboration BuyerSupplier Relationships. Journal of Marketing, 36(4): 461-475.

Kang, J., Asare, A.K., Brashear-Alejandro, T., Granot, E. and Li, P. 2018. Interorganizational drivers of channel performance: a meta-analytic structural model. Journal of Business and Industrial Marketing, 33(2): 183-195.

Kannan, V.R. and Tan, K. C. 2006. Buyer-supplier relationships: The impact of supplier selection and buyer-supplier engagement on relationship and firm performance. International Journal of Physical Distribution and Logistics Management, 36(10): 755-775.

Kozlenkova, I.V., Hult, G.T.M., Lund, D.J., Mena, J.A. and Kekec, P. 2015. The Role of Marketing Channels in Supply Chain Management. Journal of Retailing, 91(4): 586-609.

Krafft, M., Goetz, O., Mantrala, M., Sotgiu, F. and Tillmanns, S. 2015. The Evolution of Marketing Channel Research Domains and Methodologies: An Integrative Review and Future Directions. Journal of Retailing, 91(4): 569-585.

Kumari and Wadhwani M.K. 2018. Marketing Behavior of
Banana Grower in Bhagalpur District of Bihar. Economic Affairs, 63(4): 791-794

Lam, S.Y. 2004. Customer Value, Satisfaction, Loyalty and Switching Costs: An Illustration From a Business-toBusiness Service Context. Journal of the Academy of Marketing Science, 32(3): 293-311.

Lefaix-Durand, A., Kozak, R., Beauregard, R. and Poulin, D. 2009. Extending relationship value: Observations from a case study of the Canadian structural wood products industry. Journal of Business and Industrial Marketing, 24(5): 389-407.

Levens, M. 2014. Marketing: Defined Explained Applied Casebook (Second Edi). Pearson.

Lewin, J., Barry, J. and Terry, T.S. 2008. Empirical study of relationship value in industrial services. Journal of Business and Industrial Marketing, 23(4): 228-241.

Lindgreen, A., Hingley, M.K., Grant, D.B. and Morgan, R.E. 2012. Value in business and industrial marketing: Past, present, and future. Industrial Marketing Management, 41(1): 207-214.

MARS. 2014. Study of Market and Paint Consumer Profiles Cat 2013 (Vol. 10).

Matear, S. and Baxter, R. 2003. Measuring Intangible Value in Business to Business Buyer- Seller Relationships :An Intellectual Capital Perspective Roger Baxter and.

Möller, K. and Törrönen, P. 2003. Business suppliers' value creation potential. Industrial Marketing Management, 32(2): 109-118.

Morgan, R.M. and Hunt, S.D. 1994. The commitment-trust theory of relationship marketing. Journal of Marketing, 58(3): 20-38.

Palmatier, R.W. 2008. Interfirm Relational Drivers of Customer Value. Journal of Marketing, 72(4): 76-89.

Payne, A.F., Storbacka, K. and Frow, P. 2008. Managing the co-creation of value. Journal of the Academy of Marketing Science, 36(1): 83-96.

Pels, J., Brodie, R.J. and Johnston, W.J. 2004. Benchmarking business-to-business marketing practices in emerging and developed economies: Argentina compared to the USA and New Zealand. Journal of Business and Industrial Marketing, 19(6): 386-396.

Pimpa, N. 2008. Relationship value in that business-tobusiness marketing. Journal of Asia-Pacific Business, 9(3): 235-247.

Richards, K.A. and Jones, E. 2008. Customer relationship management: Finding value drivers. Industrial Marketing Management, 37(2): 120-130.

Sheth, J. 2017. Revitalizing relationship marketing. Journal of Services Marketing, 31(1): 6-10.

Skarmeas, D., Zeriti, A. and Baltas, G. 2015. Relationship Value: Drivers and Outcomes in International Marketing Channels. Journal of International Marketing PrePrint, Une, $1-44$.

Stern, L.W. and Palmatier, R.W. 2014. Marketing Channel Strategy ( $8^{\text {th }}$ ed.). Pearson. 
Stern, L.W. and Reve, T. 1980. Distribution channels as political economies: a framework for comparative analysis. The Journal of Marketing, 44(3): 52-64.

Tanskanen, K. and Aminoff, A. 2015. Buyer and supplier attractiveness in a strategic relationship - a dyadic multiple-casestudy. Industrial Marketing Management, 50: 128-141.

Ulaga, W. and Eggert, A. 2001. Developing a Standard Scale of Relationship Value in Business Markets. 17th Annual IMP Conference Proceedings., pp. 1-18.

Ulaga, W. and Eggert, A. 2003. Relationship Value in Business Markets : Development of a Measurement Scale. ISBM Report 2, 3004(814), 1-38.

Ulaga, W. and Eggert, A. 2006. Relationship value and relationship quality: Broadening the nomological network of business-to-business relationships. European Journal of Marketing, 40(3-4): 311-327.
Watson, G.F., Worm, S., Palmatier, R.W. and Ganesan, S. 2015. The Evolution of Marketing Channels: Trends and Research Directions. Journal of Retailing, 91(4): 546-568.

Weitz, B.A. and Jap, S.O. 1995. Relationship Marketing and Distribution Channels. Journal of the Academy of Marketing Science, 23(4): 305-320.

Weitz, B.A. and Jap, S.O. 1995b. Relationship Marketing and Distribution Channels, 23(4): 305-320.

Werner J. Reinartz and Kumar, V. 2003. The Impact of Customer Relationship Characteristics on Profitable Lifetime Duration. Journal of Marketing, 67(1): 77-99.

Wilson, D.T. and Jantrania, S. 1994. Understanding the Value of a Relationship. Asia-Australia Marketing Journal, 2(1): 55-66. 
